\title{
Crossing Boundaries between Nature and Artifact: Folk Music Reconsidered
}

\author{
Nancy van DEUSEN \\ Los Angeles $(\mathrm{Ca})$
}

Our artificial language has so repressed Nature, and our bourgeois lifestyle and social conventions have so dammed the flow and momentum of the sea of our passions, absolutely dried them out and diverted them, so to speak. Yet profoundly intense moments - occurring as rarely as they do - must finally be heard. They claim their rightful place, and burst forth as tone, using a mother tongue that consists of accents.

So Johann Gottfried Herder wrote, in his epochal work, Abhandlung über den Ursprung der Sprache (Herder 1993: 6-7). ${ }^{1}$ The text - actually an extended pamphlet - won the Berliner Königliche Akademie der Wissenschaften prize for the year 1770; and we have inherited its influence.

We are Herder's children. The reader of this extremely concentrated, intense work immediately notices its pervasive influence upon the shaping of a recognizable concept of folklore, in terms of its articulation of nature, giving

1 I have included the lengthier German context for this opening remark, which I have translated into English: "Unsre künstliche Sprache mag die Sprache der Natur so verdränget, unsre bürgerliche Lebensart und gesellschaftliche Artigkeit mag die Flut und das Meer der Leidenschaften so gedämmet, ausgetrocknet und abgeleitet haben, als man will; der heftigste Augenblick der Empfindung, wo und wie selten er sich finde, nimmt noch immer sein Recht wieder und tönt in seiner mütterlichen Sprache unmittelbar durch Akzente. Der auffahrende Sturm einer Leidenschaft, der plötzliche Überfall von Freude oder Froheit, Schmerz und Jammer, wenn sie tiefe Furchen in die Seele graben, ein übermannendes Gefühl von Rache, Verzweiflung, Wut, Schrecken, Grausen usw., alle kündigen sich an und jene nach ihrer Art verschieden an. So viel Gattungen von Fühlbarkeit in unsrer Natur schlummern, so viel auch Tonarten." It is difficult today to extricate this passage from a twentiethcentury reading overlain with, and influenced by Freudian hypotheses; but this passage would have been comprehensible as well - without Freudian innuendos - to a thirteenth-century reader acquainted with the Latin translations of Plato's Phaedo, as well as Aristotle's De Anima (Concerning the Soul). Both of these works, which were translated in the course of the twelfth and early thirteenth centuries, and were reviewed and commented upon by a most interested thirteenttrcentury readership, explore the essence of the soul, and its ability to accommodate conflicting passions. Herder is bringing a continuous, active tradition to the attention of his reading audience - and relying upon their ability to relate to it from the standpoint of these two authors - rather than proposing a revolutionary point of view, or advocating a radical departure from the past. Further, the works mentioned above were not solely the province of a specialist readership of "philosophers," but, rather, every literate person would have had at least an acquaintanceship with both the Phaedo, and De Anima. In other words, those who read Herder had also read these two standard works. One must also read the Abhandlung über den Ursprung der Sprache together with Herder's other works, especially his Ideen zur Philosophie der Geschichte der Menschheit. 
a rationale to collection as material (especially the collection of folksongs); of the distinguishing Merkmal, or characteristic feature related to tone, and, finally, a pronounced dichotomy, often expressed, as in the passage quoted, between a concept of the "natural" and "artificial." Once one becomes accustomed to the thick style of Herder's late eighteenth-century German, one can feel quite at home conceptually with Herder and his concept of folksong collection, that is, that one should collect folksongs, and that this collective mass formed a pure, authentic source of natural folk impulse, unpolluted by the artificiality of composition. This, at least, was the way Zoltán Kodály put it, in his Hungarian Folksong, published first in Hungarian in 1937, with the fourth edition appearing in 1969, followed by a revised English translation in $1971 .^{2}$

Or can - and should - one feel conceptually comfortable with Herder? This depends upon how one "reads" him, better, how one composes Herder, interlacing his own statements with what one also brings to the text, in effect approaching Herder as if his writings on folklore were be a virtual stockpile of material for use in conjunction with one's own beliefs. If what Herder has become is assumed, that is, if the reader inserts a now-familiar conceptualization of folklore, what Herder actually emphasizes differs significantly from what Herder himself would have brought, in terms of a late eighteenthcentury intellectual tradition, to his own essay. Uniting this influential writer with his own tradition not only gives Herder's writing a completely new cast, but grants it power as it convincingly describes not only folksong, but also medieval musical-textual material. The process in both cases, is remarkably similar. Herder has been misunderstood through the course of the twentieth century, in an indifference to, exclusion, or total ignorance of essentially medieval explanations of fundamental issues of material, nature, composition, the creative process itself, and the dichotomy between "natural" and "artifi-

2 Kodály's Folk Music of Hungary includes: 1) Oral and Written Tradition, Popular Art Song, The Old Song Tradition, Collections with Tunes, The Meaning of Folk Tradition and Classification of Folk Tradition; 2) The Primitive Stratum of Hungarian Folk Music, Connection with Related Peoples, The Eastern Origin of Hungarian Pentatonality; 3) The New Style of Folk Song, Connection between the New Song Form and the Old Tonal System, The Influence of the Popular Art Song; 4) Children's Songs, Regös Songs; 5) Dirges; 6) Reciprocal Influences in Folk Music; 7) The Traces of Art Music, Church Music, Gregorian Chant, Folk Hymns; 8) Instrumental Music, Folk Instruments, What Peasants Play on Their Instruments, Foreign Pieces of Unknown Origin; 9) Folk Tradition and Music Culture. Although the literature, especially in the Hungarian language since Kodály published the 1937 Hungarian version, is large, all of the prevalent theses appear to reinforce the contrasting categories Kodály presents, i.e. between "natural" folkmusic and constructed, or "artificial," composed music, between town or urban "constructed" (with the implication of conventional) groups of people as amalgamations - not cultures - and peasant culture, of the negative "new" compared to the authentic "old" which is "eastern" in origin from some indeterminate time past. 
cial." This paper, accordingly, will address methodological issues, with application, specifically, to the century or so of research on Hungarian folk music. Although, clearly, Herder can be taken as a point of departure, the issues are more far-reaching; interrogating the basic assumptions of folk music research during the course of the 20th century.

One is able to test the hypothesis that medieval explanations for the compositional process also best describe what is taking place compositionally in folksong by comparing the large collection of Hungarian folksongs assembled throughout this century in Budapest with the equally vast material of the medieval sequence which, due to its prominent place and function within the liturgical Mass ceremony, was sung all over the continent of Europe from approximately 875 to 1600, C. E. Hungarian folksong and the medieval Latin sequence have, for a start, two features in common. Both are characterized for the most part by one line of music; that is, vocal monophony; there are thousands of them, forming variations on themselves. Thus, methodology for their study, in both cases, must be dictated by sheer numbers of individual examples - and a methodology must be devised in order to deal with so many particulars within a general category. In the study of similarities and differences between these two musical-textual categories, folksong and sequence - which had been more distinctly divided as genres during the course of the nineteenth century than either previously had been, or currently are - several outstanding similarities have come to the fore. There were immediate possible comparisons between folksongs, documented by a century of recording and transcription, and medieval sequences which I have collected from all parts of the European continent during the course of the last fifteen years (van Deusen: 1982; 1986; 1998; forthcoming). Further, there was, in both cases, an extensive literature which could be useful for tracing the historiography of ideological/theoretical constructs generally throughout this century.

Hungarian folksong and the medieval sequence have intervallic similarities, namely a recurrent pendulum-swing occurring between the structural fifth; similarities between internal lines, and a pronounced division between melodies that are extremely stable over a relatively long period of time and a wide geographical distance, and melodies that seem, by their very nature, to contain propensity for variation. In addition, both musical types show a fluctuation between chromatic degrees (as the $b$, b-flat relationship) within the same composition, and both sequences and folksongs evidence 
similar rhythmic/syllabic patterns, based upon a common syllable-tone relationship. Both categories seemed to concentrate modal material, in that a characteristic figure (the medieval figura or Herder's Merkmal) announced the principal attribute, gesture, or what one might name a characteristic "stance" of the composition, right at the onset of the composition.

In addition, there appear to be "chunks" or defined segments of melodic material (known in medieval writing as centones or, in Latin translation, puncta) in which the melody as well as the text seemed to divide naturally into autonomous modules. These could be placed in any order without destroying what seemed to be an internal logical flow, either of the melodic line, or of textual significance. Both folksong and medieval sequences seemed to be "composed" (expressed by the Latin componere - that is, to place together) as a series of "chunks" in what appeared to be an infinitude of different arrangements, at the apparent discretion of the often anonymous "composer." It was this aspect - that of the modular chunks - among many other similarities between the two, that particularly fascinated me. I realized gradually that the principles that I had formulated concerning components of a medieval view of the compositional process in fact not only explained the medieval phenomenon, but matched the compositional process used in Hungarian folksong as well (van Deusen: 1995, pp. 108-117).

It is this area that I plan to pursue in order to show that medieval explanations and terms for discussing the compositional process are far more useful for explaining the nature of folksong - that is, have a more obvious connection to reality - than are the explanatory systems that were advanced during the course of the nineteenth century, both as the result of a misunderstanding of Herder's writing (especially, as I have suggested, the Origin of Language), and as protest against the incipient industrial revolution, particularly, but not exclusively, within German-language literature. What Herder actually wrote is quite different from its outcome, namely, a field of ethnography/folklore in which ideological viewpoints form a structure of unquestioned assumptions. Examples of these ideological constructs ${ }^{3}$ include the progressive-evolutionary point of view in a search for "origins" - in this case "Finno-Ugric layers" - hierarchies of folklore as expressions of class-

3 Both ideological constructs can be found as underlying conceptual foundations to Kodály's Folk Music of Hungay, but are much in evidence elsewhere as well. The main goal of research would appear to be an attempt to come to conclusions regarding "function, origin, and form of Hungarian folkmusic," that is, for example, "dating further back than the Hungarian conquest of the Carpathian basin" (9th c.). I would argue that these are not the only goals to be considered; and that at any rate, these stated goals should be examined for their potential fruitfulness. 
conflict and confrontation, and folklore regarded as "authentic" when compared to composition, often written, which is categorized as "artificial."I concluded that all of the research directions, seemingly taken for granted by the scholars themselves, relied heavily upon a predetermined ideology, rather than observing and communicating what appears to have actually taken place within the creative folk process; and I concluded that folk music can be explained best by medieval explanations of "material," "composition," "characteristic features (figurae)," and the emotional substance found in "modes," as exemplified by the recordings, transcriptions, and actual melodies of Hungarian folk music itself. ${ }^{4}$ I chose Hungarian folk music because of the abundance of folk material continuously collected during the 20th century, and because of the continuity of literature on this subject, primarily by Hungarian ethnomusicologists, beginning with Bartók and Kodály, and continuing to the present (Dobszay-Szendrei: 1992, pp. 43-53).

Medieval explanations of spiritual-emotional material, the compositional process, the essence of material or nature, and the differences between nature and artifice, also describe what actually takes place in folksong composition. Here is the line of reasoning followed in medieval writing concerning the composition process, to be applied as well to the problem of folksong composition. ${ }^{5}$ First, perhaps most importantly, medieval writers on music viewed music as concrete, substantial material - material that could be measured, quantified, perceived, as other materials, by the senses. Influenced by the Timaeus of Plato in Chalcidius' fourth-century translation and commentary, they understood an equivalence of emotional-intellectual material with

\footnotetext{
4 The characteristic of writing concerning folksong that gives more attention to a predetermined ideological construct than to the music itself - in fact obscuring actual music-text characteristics - is another feature that folksong and the medieval sequence in common. Scholars of the 20th century, in dealing with the thousands of examples of the sequence, have focused upon, and attempted to prove, an ideological stance, rather than drawing attention specifically and precisely to the sequence itself as a music-text situation. Often articles dealing with the sequence discuss only the opening lines; the entire sequence from beginning to end as a musical-textual composition is rarely, if ever, considered.

5 The rationale for this line of reasoning was essentially translational, since the Latin translation for the Greek term signifying conceptual subtance, hyle, that was consistently used by Chalcidius in his translation of the Timaeus of Plato was silva, an ordinary, commonplace, Latin word that signified a forest full of trees, a wood. The forest contained by its very nature, material - to burn, to make furniture, to provide shade, etc.) By the transformation or mutation of translation, a term that had largely abstract connotation within the Greek was exchanged for one that had a more substantial material dimension. This relatively simple transformation, as a key term found its way into the Latin-reading mentality of the medieval period, is crucial for an understanding of how compositional process was viewed, namely primarily as the rearrangement of existing sections or chunks of material. The sections manifested themselves as one worked with the material itself. Unformed material could be formed; and there were analogies in the natures and manners with which one could work, as well as the final products, between substantial, concrete, substance, and intellectual-emotional-conceptual material. Further, in the Latin Timaeus, silva contains within itself an “appetite to aggregate.” See Plato, Timaeus, 273.1516, 314.17-315.4.
} 
actual physical, concrete material. All of the material that was actually "available" constituted an entire repository or storehouse of material available for spiritual-intellectual "works." This concept of a storehouse of available material was reinforced by Augustine, who, in his Confessions, states that memoria - an expanded concept of memory - formed a repository or storehouse for composition. ${ }^{6}$ (A topic mentioned frequently by medieval authors is that of the biblical scriptures as a dense forest or "thicket" of material, from which one could help oneself.)

From this emphasis on material, a conceptual framework can be articulated:

1) There is a relationship of material and, particularly, pieces of material to cognition, recognition, and memory, since material always contains properties evidenced by characteristics. Characteristic emergent properties are known as figurae and are discussed frequently in medieval writing; they correspond to Merkmale for Herder.

2) Material can, by its nature, be delimited into chunks - Greek centones, translated into the Latin puncta.

3) The compositional process involves placing these available "chunks" into an order.

This order is individual and can be quite personal, according to the will of the person who places them together. Inevitably all human beings are in fact "composers," in that they invariably "do something" with available material. One question that interests neither medieval writers nor folk composers-musicians is the question of origin: where does the available material come from? In the case of medieval sequences, it is extremely rare throughout the entire medieval period that a sequence composer is mentioned in any context, and when this does occur, it is usually with another apparent agenda on the part of the writer; in the case of folk musicians, the material is simply available to them. The folk musicians do not apparently ask from whence

\footnotetext{
6 Augustine himself often in his writing makes use of the principle I have delineated above, that is, chunks of material from many sources, in which his main contribution to the compositional process is bringing them all together in careful, reflective combination. See the Confessions (30), p. 71: "O Lord our God, under the covering of your wings (Exod. 19,4) we set our hope. Protect us and bear us up. It is you who will carry us; you will bear us up from our infancy until old age (Isa. 46,4). When you are our firm support, then it is firm indeed, but when our support rests on our own strength, it is infirmity. Our good is life with you for ever, and because we turned away from that, we became twisted. Let us now return to you that we may not be overturned. Our good is life with you and suffers no deficiency (Ps. 101,28); for you yourself are that good. We have no fear that there is no home to which we may return because we fell from it. During our absence our house suffers no ruin; it is your eternity." Chadwick notes that the frequent Latin plays on words cannot be reproduced in translation. See also edition, pp. 160f, 184, $222,256,280$. See especially p. 222, in which forest as "full of deer," also providing food to be digested, and the scriptures as a forest, close and opaque with substance, is presented. Augustine treats memory, pp. 179-220; as the "stomach of the mind," p. 191.
} 
this pre-existent material comes, nor do they inquire after its origin. The accessible musical-textual material is, quite simply, there. Material reveals its properties through contact. As with most materials, such as bread dough, one must actually work with the material in order to understand its properties (Dobszay-Szendrei: 1992, p. 219). ${ }^{7}$

In the past, one reaction to the sheer vastness of folksong material has been classifying it within types (Járdányi: 1962; 1963; 1965; 19698). Many other ideological directions have been taken and can be observed - a witness to the progression of theoretical constructs used successively in the course of this century. ${ }^{9}$ This contribution to the problem will, on the other hand, present a medieval explanation for the compositional process within Hungarian folkmusic. What is essentially a medieval point of view has the capacity to provide analytical conceptual vocabulary. Firstly, within available material, characteristic figurae indicate the potential of that material. Material, both concrete and artistic, breaks by its very nature into chunks, or can be broken up at will. These sections or chunks can be, and are put together as the result of the compositional process. All human beings engage in this process.

A medieval analogy to this process would have been, to our way of thinking, startlingly mundane, and, perhaps, embarrassingly substantial. An example of just how concrete these "chunks" of building material could be is the following. The great medieval English Cistercian abbeys of the late 12th and early 13th centuries, such as Fountains and Riveaux, were not demolished primarily by vandalism, but, rather, each successive generation from the sixteenth century on, simply helped itself to the buildings, appropriating material, block by block, in order to build their own. So it is with compositions composed of chunks of material that is both musical and textual.

Within folksong, an exemplification of the medieval description of composition as the placing together of pre-existent chunks can be articulated. I have chosen a type from hundreds of types into which the collected folksongs in the Budapest archive were, during the course of this century, ordered by several generations of Hungarian ethnomusicologists. In fact, they are still ordering the folksongs, and discussing what it is that a type is. Rather than going into the question of how to place many divergent so-called "vari-

\footnotetext{
7 László Dobszay writes of a “conformity of substance...," cf. Catalogue, chapter “Lament Style,” p. 219.

${ }^{8} \mathrm{He}$ gives the impression repeatedly that classification into types is unquestionably the way to proceed.

9 A comprehensive, thorough review of the historiography of folksong research and writing throughout the entire twentieth century lies outside the scope of a journal article, to be included in my forthcoming study of folkmusic in Central Europe.
} 
ations" into a type, ${ }^{10}$ and on what basis - what is, in fact, a type, in contrast to a variation, an alternative analytical system follows. First, this "type" appears to divide itself into two "chunks," that is, centones or puncta (van Deusen: 1995,108). Each chunk appears to have one characteristic figura, and it was interesting to me, in listening to the many recordings of this type, that each singer selected a different characteristic figura. In "chunk 1," the descending repeated half step is significant; in "chunk 2," the upward step, downward third figura is characteristic. ${ }^{11}$ These figurae not only give - as well as identify - characteristic features as they emerge, one by one; but they contain potential for the further use of this material resource. ${ }^{12}$ Figurae are both formative, in that they generate recognition, and recognizable, since what is delineatory and characteristic can be more easily stored in the memory. Other examples of figurae are the formative, recognizable figurae of all of the letters of the alphabet; and, of course, a perfect analogy to this concept of characteristic, indicative figura was found in music notational figurae. Figurae indicate innate propensities of melodic substance; that is, externally show ways in which all of the melodies within the same mode use a recognizable melodic material in common. ${ }^{13}$

A comparison of this type to other types that use the same melodic or modal material showed that there was more deviation between melodies of

10 The problem of "variation," what constitutes a variation, and how one can be differentiated from a separate "melody" or "type" is another problem shared by both folksong and medieval research.

11 A "chunk" can be defined as what could be easily retained within the memory, or spoken using one breath, or perceived by at least one person as a chunk. Quintilian, in his highly influential work on the teaching of public speaking (born 35 C.E.), frequently contrasts "rough material," or a "rough block" with an "element" that has been carefully worked over. Sometimes, he writes, the untrained are thought to be the more vigorous. This opinion is due primarily to the erroneous judgement of bad critics, who think that true vigour is all the greater for its lack of art, that slaves or peasants in clumping together a congestion of bits achieve laudable results. What good then is teaching? He asks, and answers his own question. Further, Quintilian uses silva to signify a rough material that has not been honed sufficiently. The writer, in a white heat, impetuously takes on the entire mass of material without carefully considering what to do with it, and then, after reflection, proceeds step by step. The result is silva-a tangled wood of material that has not been fashioned into a purposeful object, in this case, a speech. It is, of course, significant that Quintilian is describing and teaching rhetoric, thus making no distinction between what is spoken and what is written down, between the oral and the written compositional process. Concepts signifying a congestion. amalgamation, or unordered repository contrast with "block that has been polished." (See Quintilian, Institutio oratoria, Books II.XI.I; III.I.I; XIII.III.17. Quintilian's style is ironic, witty and loaded with examples, many musical ones, which explain why he continued to be read and his advice taken seriously for at least fifteen hundred years.) Isidore of Seville, in his seventh-century Etymologies or the Origins of Words, defined a chunk as a compositional block similar to Virgil's verse, the building-blocks of approximately similar size used for constructing the Aeneid.

12 I am avoiding the much later hypothetically evolutionary implications of the term "emergent."

13 With regard to terms used, conceptual similarity is often lost in translation, since the Latin term figura indicates alphabetical letter, number, geometric figure, and components of musical notation. In English, three separate entities are formed in the mind by the use of three different words, that is, letter, number, notation, thus obscuring or even obliterating the connection the identical Latin word transmits. 
the same type than between the types themselves. ${ }^{14}$ With astonishing reliability, the modal material itself - always the same group of tones, occurring in characteristic successions - unified all of the melodies that used it, since basically the same tones were used, in many of the same ways. On reflection, the implications of this observation were amazing, since they actually negated the entire rationale for using types, that is to say, there is as much variance within types as between types. This led to the conclusion that the whole idea of "type," similar to the idea of "repertory" in historical studies, implied more conclusion than it contained, and promised more in terms of delimitation and affinity pattern than it delivered. In addition, I found that essential differences, even in the character of the melody, between transcribed melodies had much more to do with performative differences, that is, differences imposed upon a textual-musical material by individuals, than with strictly musical-textual parameters. These essential differences further removed individual examples from a system of affinities and limitation set up or implied by type, and questioned the value of a concept of type, as well as its implication of basic structural category with adherent subordinates, to explain the relationship of melodies to one another. "Type" also implied a comparison of structure with emendation or ornamentation, a comparison that did not appear to be appropriate to the numerous examples at hand.

These essential differences included:

1) very lightly-touched adjacent tones

2) the ambiguity of b/b-natural used within the same short melody

3 ) the timbre of the voice, the absence or presence of vibrato, expressive gesture, or an inherent willingness and power to communicate

4) tempo differences within a piece

5) addition of microtones

6) age of singer, or, generally, unintended characteristics ${ }^{15}$

7) variarion in actual pitch, vocal mannerisms, coupled with noise factor

8 ) each singer reinforced a different structural reality, or seemed to emphasize a characteristic gesture of the melody.

Let us compare the transcriptions of the "type" selected. Type 160740 was recorded, transcribed, and published first in 1900; recorded and pub-

\footnotetext{
14 Because of limitations of space, other examples could not be given within this context; however, the general principle stated here, applied to countless other examples, so much so, that it constituted a general rule.

15 At the risk of stating the obvious: an example of this is that, generally speaking, with increased age, some voices may lose the ability to reproduce pitch with clarity, or to conform pitch to intention, resulting in the absorption of musical communication into social context. An older person may enjoy respect as a member of the community, but no longer for primarily musical reasons, thus rendering recorded transmission of a melody essentially useless for musical purposes.
} 
lished again in 1906 by Kodály, who successively published the same melody again in 1909, 1911, 1916; the melody was also published by Bartók and Benjamin Rajeczky. What was seen as belonging to the same "type" was recorded in the region of Nyitra, in 1937, 1956, 1958 (three different versions), 1961, 1969, 1971, 1976; in the region of Hont in 1965, and in Nógrád in $1940,1955,1965,1976$, in what can be seen as three waves of research, that is, in the early twenties, mid-fifties, and mid-seventies. A continuity, however, was established by singers who were at least eighty-five years old in the seventies. All of these counties are presently in Slovakia. The type in question is associated with a group of songs sung by single young people during the days before a wedding (Szentyiványi).

In listening to these recordings, I noticed that every recording was completely different in nearly every significant respect. In spite of this, there was a common way of using modal material that contributed to the flavor or taste of the composition (van Deusen: 1989, 1-45). ${ }^{16}$

It seemed to me that a common melodic repository, in terms of chunks of musical textual material had been used with these differences:

1) Nearly all of the texts differed. Texts were recombined with chunks or modules placed in different orders, or were simply reworked.

2) Basic rhythmic gestures, or figurae, differed.

3) Structural emphasis differed significantly. For example, one singer from Nyitra basically sang only $\underline{\mathrm{d}}$ - all the rest of the melody literally fell away (see Example 3).

4) The affective character or essential affect within this group of two chunks as well as the effect the composition made differed significantly. All of these differences have been noted to some extent in the transcriptions.

5) Each singer reshaped and reformed song material. Each had taken the material in terms of tonal proclivities and potentiality and had reformed it. This also included text.

6) Some of the "variants" noted by the transcribers seemed to be an inability - or a deficient performative-expressive power - to reproduce intervallic change. This factor seemed to be responsible for the "recitation style" which Benjamin Rajeczky noted and attributed to comparative antiquity (Rajeczky; 1957; 1962; 1964; 1967; 1973). ${ }^{17}$

\footnotetext{
16 "Flavor" or "taste" adhering to musical substance would have been one medieval manner of expressing these differences, but Australian Aboriginal musician-composers also identify what would be differences in constructive mode as flavor, taste, or how a combination of tones feel in the mouth, according to Catherine J. Ellis (personal conversation, 1985).

17 Benjamin Rajeczky was fascinated with connections between medieval music and folkmusic in the above-mentioned articles. All of these short articles, however, appear to be influenced by much earlier writing concerning a hypothetical relationship to the Finnish "Lament Style" and allude to connections rather than thoroughly investigating what could be their source. What was offered as a hypothesis by B. Szabolcsi in 1933-34 (he was not alone at the time) almost imperceptibly moved into the area of established fact as a basis for further research, for example in the 1956 publication of Werner Danckert.
} 
What can be made of this? Coming, as I do, from behind, that is, from many years of experience with the ways in which medieval writers explained composition to themselves and others, it seemed to me that their explanations described precisely what I had observed in the recordings and transcriptions I had heard and seen. All of it brought to mind three ways in which the medieval orientation of music as a material discipline, as well as medieval discussions of the problem of particulars (or differentiae) within the generality of material bring understanding to the questions at hand.

First, foremost, the question of material. Within a basic, commonlyshared material of tones, there is inherent potential for material to be used in certain manners, that is, modes. This is the reason why all of the melodies using D-dorian modal material resemble one another. This is certainly true of medieval cantus, which formed a direct analogy to the above-mentioned abstraction, but it is true, as well, of folk melodies. All that use a certain material ( $\mathrm{g}-\mathrm{d}, \mathrm{g}$ downwards to $\mathrm{d}$ ) resemble one another because they make use of the same material. One must remember that the medieval modal system was neither scalar nor primarily classificatory. The main idea is that tonal mate-

\section{Example}

Although variables have been confined to a limited period, and to a group of transcriptions all made and published by Kodály, one may nevertheless observe the wide spectrum that is possible within one "type."

Type: $160740 / 1,2$
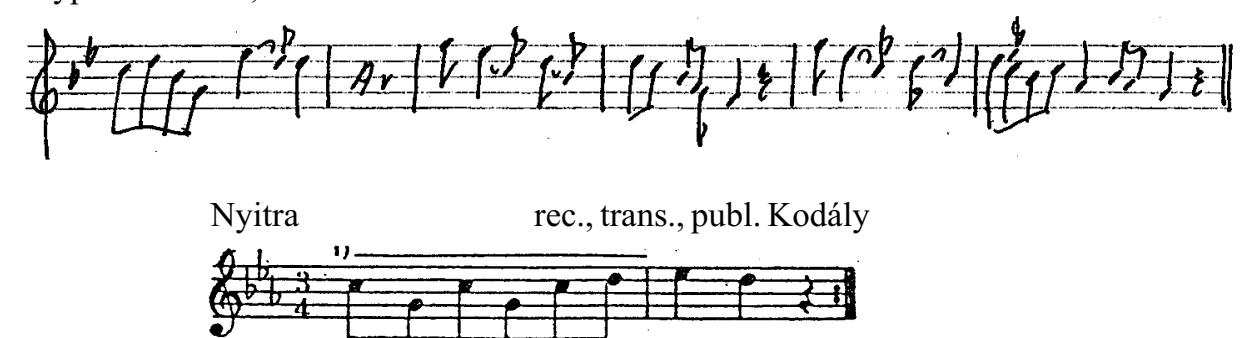

1. Szénty-i-via-nyi tisz-tia bú-zá

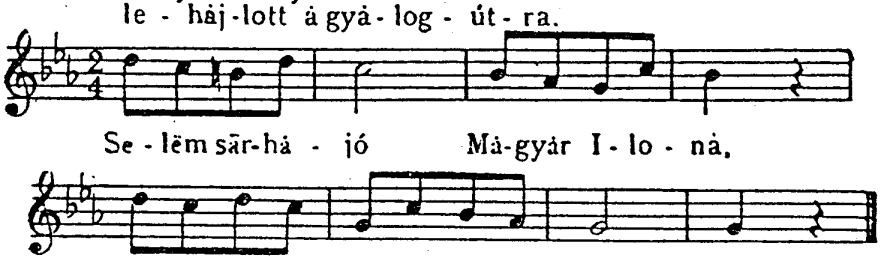

hì-ji fö-lyö gyọ̈ngykoszorú - jả, gyöngy.

Ethnographia (20), 1909, 32 (transposed) 
rial to be used must be appropriated, and its material properties and proclivities (or proprietates) recognized as well by the singer-musician-composer.

Secondly, material is known by characteristic figurae which give differentiae - Herder's Merkmale, in which "alle kündigen sich an und jene nach ihrer Art verschieden an," to refer again to our opening quotation. This is also true of folksong. All of the parameters might change or be reformed, but at least one figura, as characteristic, indicated that melody. In the large group of melodies using the same material, various characteristic properties, as melodic, or rhythmic gestures, indicated by the figurae of transcription were constantly emerging from this material.

Example cont.

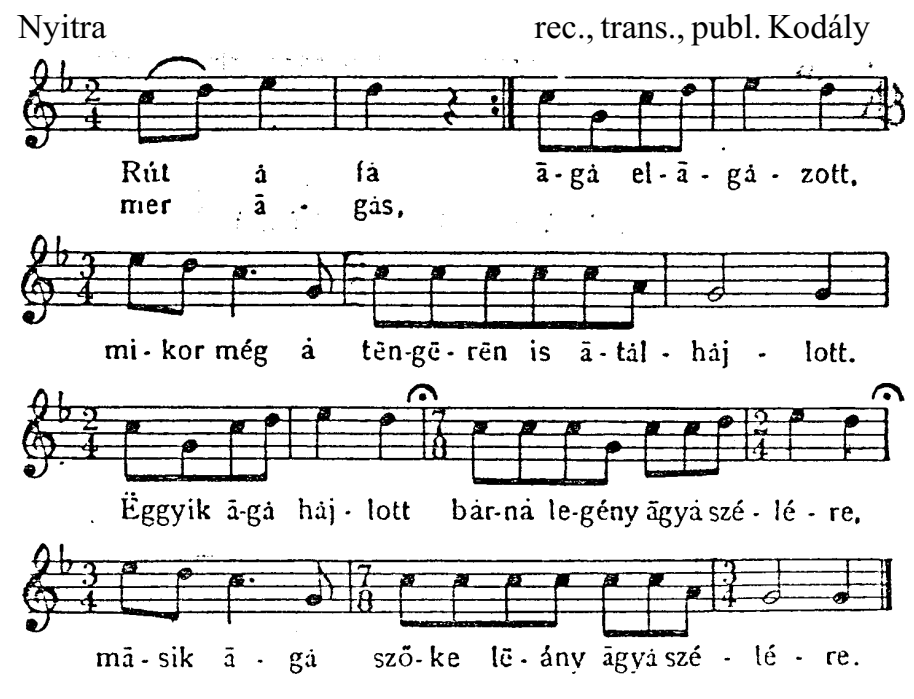

Ethnographia, 1909: 33

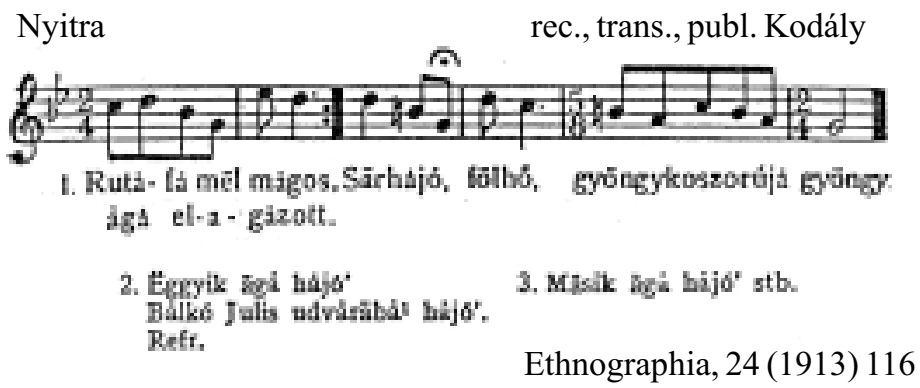


Thirdly, composition was regarded as placing chunks of material together - notice that the articulation of this process is "placing chunks," not "developing from layers." The songs, by the nature of their material, seemed to be susceptible to being divided into chunks. This is true of cantus, or medieval one-line melodies sung usually within a liturgical ceremony, and folksong; but it is true, as well, for eighteenth-century instrumental music. Human beings, whoever they are, whether a singer - who had been composing songs for many years - or Haydn, or Bartók, appropriate musical materials and compose, that is, recombine, place in an order that seems to them to be "in order," into a composition. The point of view can be discussed that the medieval explanation of natura (nature) as preexistent musical material, and artificialis - what all humans do with musical material - may be closer to the reality of the folksong practice under observation, than the underlying as-
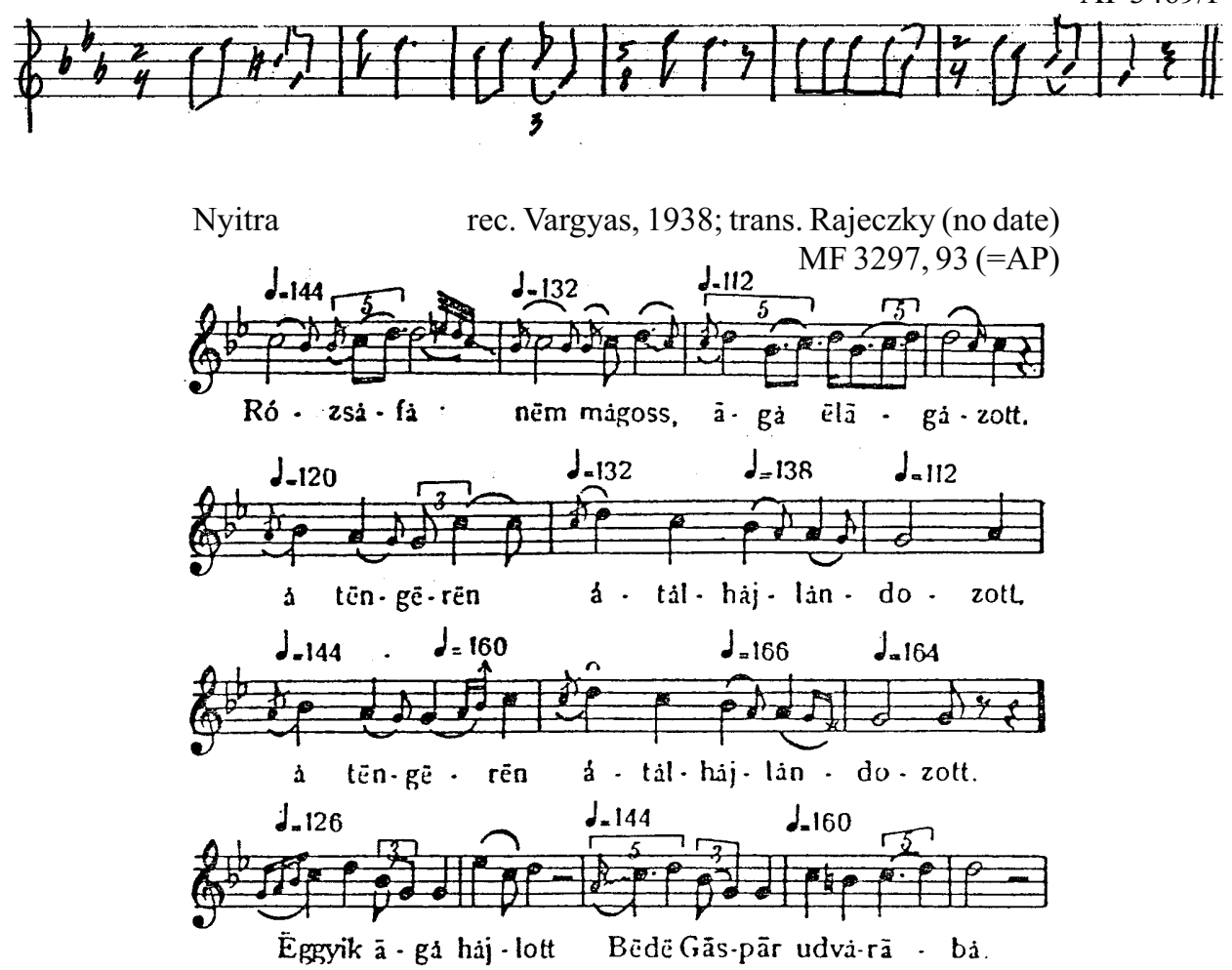
sumption that placed folksong in a dialectical position of natural over against "composed" music. Both are composed. There is no dichotomy, with respect at least to process, between so-called "folkmusic" and "art music" (Hädecke: 1993). ${ }^{18}$

In conclusion, a final medieval point. Transcription, as notational figurae for musical material, are, like all figurae, delineatory of substance, and formed as metaphors - in this case, metaphors for sound. The century of transcriptions, in some cases, of the same melodies, demonstrates that transcription exhibits yet another area of composition, in that each transcriber, using the same material, reformed and recombined that material. Each composed according to his or her own structural persuasion and will, and for his or her own use. Some transcribers (transcriptions ca. 1900-present) set forth melodic material (Bartók and Kodály), intervallic structure (Pál Járdányi, L. Dobszay, J. Szendrei) others expressed what they considered to be ornamentation (Lajos Vargyas, Benjamin Rajeczky, Pál Péter Domokos, Mária Domokos, Katalin Paksa, Lujza Tari), others the performative changes between verses (Benjamin Rajeczky, János Bereczky) still others, the addition of noise factor, or they concentrated on the use of instruments (P. P. Domokos, Bálint Sárosi, Tari) and the pursuit of types, hoping to find Finno-Ugric layers (Járdányi, Béla C. Nagy, Bence Szabolcsi, Vargyas, and László Vikár). Transcription, rather than presenting an equivalence in which one believed that one could come closer and closer to absolute, "authentic" folkmusic, was always a translation, a series of metaphors placed together according to the transcriber's own will, and to serve his or her own purposes. ${ }^{19}$

It was astonishing that a single recording, for example, by Béla Bartók, resulted in fifteen or more transcriptions made according to different systems of choice on the parts of the transcribers. Listening to recordings and comparing them with multiple transcriptions has led me to the conclusion that composition, or realigning of "pre-existent material" takes place whenever human beings deal with musical-textual substance. No two melodies for the same text or transcriptions of the same recording were the same. Further, although results differ, just as Haydn and Bartók used melodies as

\footnotetext{
18 How it came about that folksong could be considered to be "natural" as opposed to "artificial" or "composed music" is, a complex question that has to do at least partially with initial reaction to the industrial revolution ca. 1770, and well into the nineteenth century, particularly, but not exclusively, within German language literature.

19 Identifying the transcriptional direction and focus of each of these transcribers also outlines a historigraphy of ideology as well as demonstrating a series of constantly-changing - as well as intensely personal - analytical priorities throughout the twentieth century. This will form the substance of a forthcoming study that focuses on the transcriptional process, using the example of Hungarian folksong transcription throughout this century.
} 
compositional material, so singer-composers in Transylvania also use received melodies as material. Folk composers place material together in chunks. Transcribers also add a compositional factor, and performance aptitude and style still a further dimension. Thus, all musica instrumentalis, or music produced by human beings in any way, is "artificial," using "nature," as "pre-existent material," which is just how medieval writers put it. ${ }^{20}$

\section{References Cited}

Archives (AP)

Series of piral discs of recordings in the Folk Music Archives of the Hungarian Academy of Sciences, Institute for Musicology, Budapest

ARISTOTLE

1986 De Anima (Concerning the Soul), [ed., transl.] Hugh Lawson-Tangred, London: Penguin Books

Augustine

1991 Confessions. Translated with an introduction and notes, Henry Chadwick, Oxford: Oxford University Press

Bose, Fritz

1938 “Typen der Volksmusik in Karelian,” Archiv für Musikforschung 3, pp. 96-118

DANCKERT, Werner

1956 “Melodiestil der Ob-Ugrier," Acta Musicologia 28, pp. 122-135

DOBSZAY, László and SZENDREI, Janka

1992 Catalogue of Hungarian Folksong Types Arranged According to Styles, Budapest: Institute for Musicology of the Hungarian Academy of Sciences

ELLIS, Catherine J.

1985 conversations and shared seminar at the University of New England, Armidale, New South Wales, Australia May-July

HÄDECKE, Wolfgang

1993 Poeten und Maschinen. Deutsche Dichter als Zeugen der Industrialisierung, Munich/Vienna: Carl Hauser Verlag

HERDER, Johann Gottfried

1770/1993 Abhandlung über den Ursprung der Sprache [repr.]. Stuttgart: Philipp Reclam Universal-Bibliothek

1784-1791 Ideen zur Philosophie der Geschichte der Menschheit [ed.] Ernst Naumann, Herders Werke. Auswahl in acht Teilen auf Grund der Hempelschen Ausgabe, Berlin/Leipzig: Deutsches Verlagshaus Bong

20 Although a thorough discussion of this aspect lies outside the scope of the present study, geography or place was of great importance as an explanatory feature. In a consideration of the music of Central Europe, again, the distinction between composed, "art music" and "folkmusic" is blurred, and, in fact, is not the relevant differentiating topic, rather, place itself is the overriding consideration. For example, music performed almost exclusively by Hungarian orchestras and by solo musicians in Budapest is music by Central European composers. 
ISIDORE of Seville

1911 Etymologiarum sive originum libri XX, [ed.] W. M. Lindsay, Oxford: Oxford University Press

JÁRDÁNYI, Pál

1962 "Die Ordnung der ungarischen Volkslieder," Studia Musicologica 2, pp. 3-32

1963 "Bartók und die Ordnung der Vollcslieder," Studia Musicologia 5, pp. $435-448$

1965 "Experiences and Results in Systematizing Hungarian Folk-Songs," Studia Musicologica 7, pp. 287-291

1969 "Die neue Ordnung der ungarischen Volkslieder," Methoden der Klassifikation von Volksliedweisen, Bratislava: Slowakische Akademie der Wissenschaften,

KoDÁLY, Zoltán Institut für Musikwissenschaft (Simposia II), pp. 123-133

1937 Magyar népzene, Budapest: Hungarian Academy of Sciences

1969 Magyar népzene, 4th Hungarian ed., Budapest: Hungarian Academy of Sciences

1971 Folk Music of Hungary, 2nd English ed., Lajos VARGYAS, Budapest: Hungarian Academy of Sciences

1974 Collected Writings, Speeches and Statements. [ed.] Ferenc BóNIS, Budapest: Hungarian Academy of Sciences

PLATO

1950 Phaedo, [ed.] L. Minio-Paluello (Plato latinus II) London/Leiden: Brill

1975 Timaeus: Timaeus a Calcidio translatus commentarioque instructus, [ed.] J H. Waszink (Plato latinus IV) London/Leiden: Brill

QUINTILIAN

1960 Institutio oratoria (4 vols), [ed., transl.], H. E. Butler (Loeb Classical Library) Cambridge, Massachusetts: Harvard University Press

RAJECZKY, Benjamin

1957 "Typen ungarischer Klagelieder," Deutsches Jahrbuch für Volkskunde 3, pp. $31-46$

1962 "Über eine Sondergruppe der ungarischen Klagelieder," Zhomik na zardoni zivot in obicaje Knj. 40, pp. 413-421

1964 "Zur Ambitusfrage der Klagelieder," Studia Musicologica 6, pp. 375-380

1967 "Über die Melodie Nr 773 der Monumenta Monodica I," Festschrift Bruno Stäblein zum 70. Geburtstag, [ed.), Martin Ruhnke, Kassel: Bärenreiter-Verlag, pp. 191-194

1973 "Vorstrophische Formen in Ungarn," Analyse und Klassifikation von Volksmelodien (Bericht über die 3. Arbeitstagung der Study Group of Folk Music Systematization beim International Folk Music Council von 24 bis 28 Oktober 1967 in Radziejowice), [ed.] D. Stockmann, J. Steszewski, Cracow: Palskice Wydawn Muzyczne, pp. 93-99

SZABOLCSI, Bence

1933 "Osztják hősdalok - magyar siratók melódiái (Ostyak Heroic Songs-Melodies of Hungarian Laments)," Ethnographia 44, pp. 71-75 
1934 "Népvándorláskori elemek a magyar népzenében (Elements of the Migration Period in Hungarian Folk Music)," Ethnographia 45, pp. 138-156

1946 "A régi nagykultúrák dallamossága (Die Melodiewelt alter Hochkulturen)," Ethnographia 57,pp. 1-13

Transcriptions

ca. 1900-present Transcriptions made by folk music researchers, Béla Bartók, László Dobszay, Mária Domokos, Pál Péter Domokos, Pál Járdányi, Zoltán Kodály, Béla C. Nagy, Imre Olsvai, Katalin Paksa, Benjamin Rajeczky, Bálint Sárosi, Janka Szendrei, Lujza Tari, Lajos Vargyas, László Vikár, Budapest: Archives of the Institute for Musicology of the Hungarian Academy of Sciences

van DEUSEN, Nancy

1982 "The Medieval Latin Sequence: A Complete Catalogue of the Sources and Editions of the Texts and Melodies," Journal of the Plainsong and Medieval Music Society 5, pp. 56-60 1986 "The Use and Significance of the Sequence," Musica Disciplina 40, pp. 1-46

1989 The Harp and the Soul: Essays in Medieval Music. New York: Mellen Press, pp. $1-45$

1995 Theology and the Early University: The Case of Robert Grosseteste and Anonymous IV, Leiden/New York: Brill

1998 "'Retheorizing' the Sequence and the Question of 'Repertory"' Musica Disciplina

forthcoming The Latin Sequence, 900-1600 (4 vols), Munich: Henle-Verlag (RISM) 